Revised version

In: E. Lichtfouse (Ed.) Climate Change, Intercropping, Pest Control and Beneficial Microorganisms. Sustainable Agriculture Reviews, Vol. 2. Springer, pp. 1-7. DOI: 10.1007/978-90-481-2716-0_1

\title{
Climate change, society issues and sustainable agriculture
}

\author{
Eric Lichtfouse
}

INRA, Department of Environment and Agronomy, CMSE-PME, 17, rue Sully, 21000 Dijon, France. E-mail: Eric.Lichtfouse@dijon.inra.fr

\begin{abstract}
Despite its prediction 100 years ago by scientists studying $\mathrm{CO}_{2}$, man-made climate change has been officially recognised only in 2007 by the Nobel prize committee. Climate changes since the industrial revolution have already deeply impacted ecosystems. I report major impacts of climate change on waters, terrestrial ecosystems, agriculture, and economy in Europe. The lesson of the climate change story is that humans do not learn from scientists until it really hurts. Furthermore, all society issues cannot be solved anymore using the old, painkiller approach because all issues are now huge, linked, global and fast-developing. In that respect, actual society structures are probably outdated. Here, agronomists are the most advanced scientists to solve society issues because they master the study of complex systems, from the molecule to the global scale. Now more than ever agriculture is a central point to which all society issues are bound. Indeed, humans eat food.
\end{abstract}

Keywords: climate change, $\mathrm{CO}_{2}$, agriculture, Europe climate, greenhouse gas, temperature, soil C, plant, birds, flood, growing season, drought, food price

If you do not change direction, you may end up where you are heading. Lao Tsu

\section{A 100 years-old prediction}

More than 100 years ago, the Nobel Prize winner Svante Arrhenius (1859-1927) estimated that a doubling of atmospheric $\mathrm{CO}_{2}$ concentration would cause a temperature rise of about $+5-6{ }^{\circ} \mathrm{C}$ (Arrhenius, 1896, Wikipedia). Remarkably, his crude estimate is larger but not greatly different from the $+2.0-4.5{ }^{\circ} \mathrm{C}$ rise now estimated by the Intergovernmental Panel on Climate Change (IPCC, 2007). Combining his calculations with existing work suggesting that the burning of fossil fuels could significantly alter the concentration of carbon dioxide in the atmosphere (Högbom, 1894), Arrhenius later became the first person to predict the possibility of man-made global warming (Arrhenius, 1908, Weart, 2008).

Now, the recent record of atmospheric $\mathrm{CO}_{2}$ levels at the Mauna Loa Observatory in Hawaii, known as the "Keeling curve", clearly shows a steady increase from 1958 (Figure 1, Keeling et al., 2001, 2005, Scripps, 2008). Moreover, the comparison of modern $\mathrm{CO}_{2}$ levels with ancient ones shows clearly that atmospheric $\mathrm{CO}_{2}$ has now reached an unprecedented high level during the last 400,000 years, reaching $383 \mathrm{ppm}$ in 2007 (Figure 2). Despite accumulating evidence from various science fields, the human origin of climate change has been challenged during the last 30 years. Finally, in 2007, the IPCC and Albert Arnold (Al) Gore Jr. were awarded of the Nobel Peace Prize "for their efforts to build up and disseminate greater knowledge about man-made climate change, and to lay the foundations for the measures that are needed to counteract such change". In the next section I report some effects of climate change in Europe (see also Feehan et al., 2009; Jones et al., 2009, Lavalle et al., 2009). 
$\mathrm{CO}_{2}$ atmospheric concentration 1958-2007 (ppm)

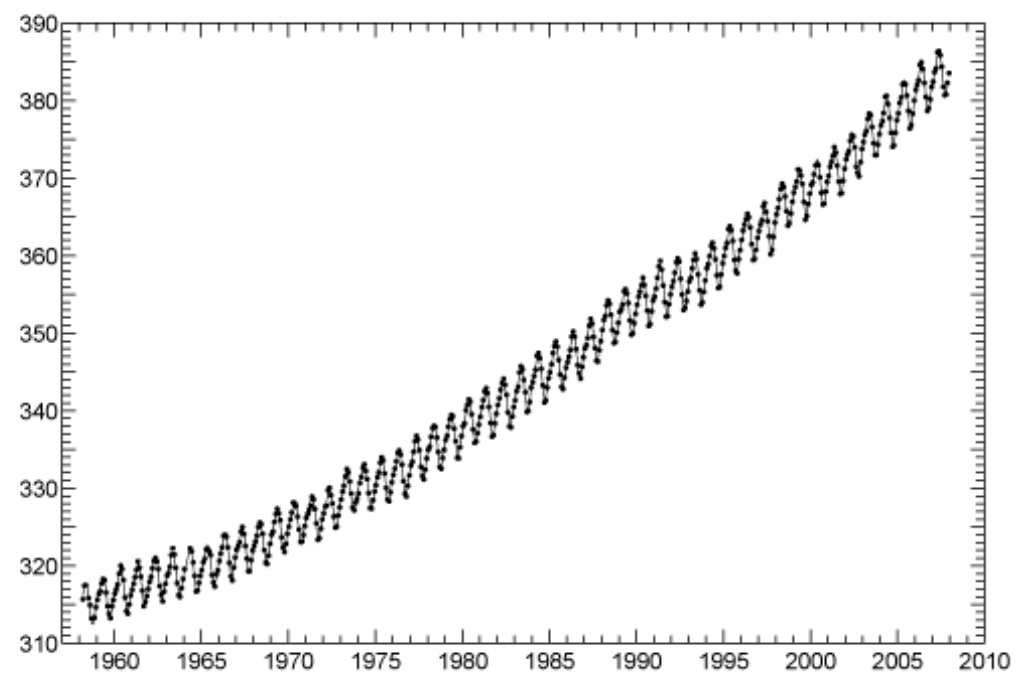

Figure 1. The Keeling curve. Concentration of atmospheric $\mathrm{CO}_{2}$ recorded at the Mauna Loa Observatory, Hawaii. The increase from 1958 to 2007 is driven by the burning of fossil fuels. The short annual variations reflect the seasonal growth and decay of land plants in the northern hemisphere. The data is from the Scripps $\mathrm{CO}_{2}$ program. Reprinted with permission of Dr. Ralph Keeling.
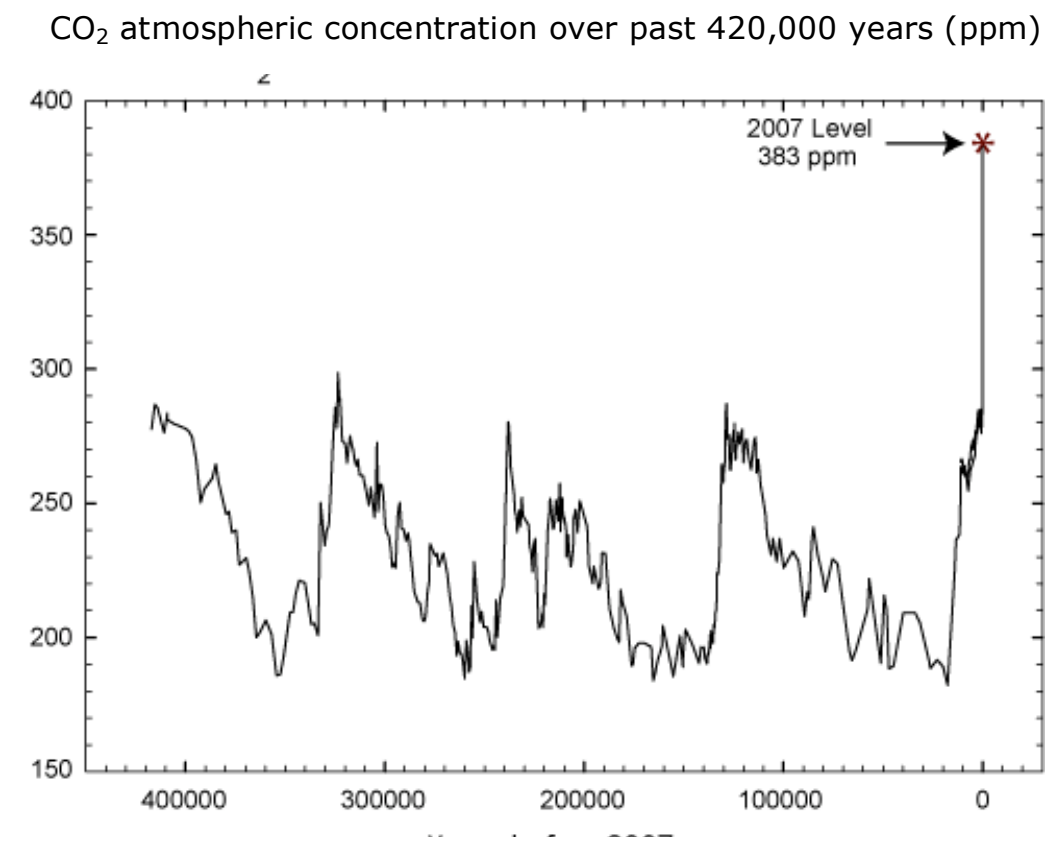

Figure 2. $\mathrm{CO}_{2}$ concentrations over the past 420,000 years. The figure shows that in 2007 the $\mathrm{CO}_{2}$ level has reached an unprecedented high level of $383 \mathrm{ppm}$. During ice ages, the $\mathrm{CO}_{2}$ levels were around $200 \mathrm{ppm}$, and during the warmer interglacial periods, the levels were around $280 \mathrm{ppm}$. Ancient data are based on reconstructions from polar ice cores. Modern data are from the Mauna Loa record of the Scripps $\mathrm{CO}_{2}$ program. Reprinted with permission of Dr. Ralph Keeling. 


\section{Climate change in Europe}

\subsection{Impact on climate and water}

The European Environment Agency has recently reviewed major observed and projected climate changes in Europe (EEA-JRC-WHO, 2008). Here I report the major changes that are relevant for agriculture. In Europe, the mean temperature for land has increased by $+1.2^{\circ} \mathrm{C}$ compared with preindustrial times. There have been more frequent hot extremes and less frequent cold extremes in the last 50 years. During the 20th century, precipitation has increased by $+10-40 \%$ in Northern Europe, and decreased by up to $-20 \%$ in some southern parts. The intensity of precipitation events has increased in the past 50 years. Dry periods are projected to increase in Southern Europe. Annual river flows have increased north and decreased south. Strong seasonal changes such as lower flows in summer and higher flows in winter are expected. Droughts will increase, notably in summer and in the south. Climate change has increased ozone concentrations in central and south-western Europe. European glaciers have lost $33 \%$ of their volume since 1850, with loss accelerating since 1980 . Snow cover has decreased by $-13 \%$ during the last 40 years. Mountain permafrost is reducing due to temperature increase. Temperatures of lakes and rivers have increased by $+1-3^{\circ} \mathrm{C}$ during the 20 th century.

\subsection{Impact on terrestrial ecosystems}

Warmer temperatures, notably in winter, have shifted plant species northward and uphill. The rate of change will exceed the ability of many species to adapt. Seasonal events in plants are occurring earlier as shown by spring occurring 7 days earlier in 2000 than in 1971, on average. Birds, insects and animals are moving northward and uphill. The life cycles of many species such as birds, frogs and butterflies are advancing. Information on the effect of climate change on soil is scarce. Both rising temperatures and changing precipitation may lead to a decrease of soil organic carbon, and, in turn, an increase of $\mathrm{CO}_{2}$ emissions. Rainfall changes should also increase soil erosion. In Mediterranean parts and central-eastern Europe intense soil degradation may lead to irreversible desertification.

\subsection{Impact on agriculture}

Climate change is affecting the growing season and yields. In the north, the length of the growing season has increased, favouring the introduction of novel crops. Whereas in the south, the length of the growing season has decreased locally. Flowering and maturity of plant species occur 2-3 weeks earlier, thus inducing a higher risk of frost damage in spring. Extreme climate events such as the 2003 heat wave and the 2007 spring drought have increased the variability of crop yields. In Mediterranean areas the water demand for agriculture has increased by $+50-70 \%$. In continental Europe, most forest are growing faster due to better management, higher $\mathrm{N}$ deposition, less acidification, increasing temperature, and increasing atmospheric $\mathrm{CO}_{2}$ concentrations. Drought and warm winter increase pest populations. Temperature increase will increase the risk of forest fires.

\subsection{Impact on economy}

Since 1980 , about $90 \%$ of natural disasters are due to weather and climate. They represent $95 \%$ of economic losses caused by catastrophic events. Losses due to climate events have increased during the past 25 years. The economic losses as a consequence of extreme flood in central Europe in 2002 were estimated at 17.4 billion Euro. The economic losses as a consequence of the hot 2003 summer were estimated at 10 billion Euro.

\section{A novel approach to solve society issues}

The lesson of the history of climate change is that humans do not learn from scientists predictions until it really hurts. This principle has always been true through history. It can easily be applied to most current society issues. What has changed, however, is the nature of today's negative impacts. While impacts were mainly small, local, and slow to develop before the industrial revolution, they are now huge, global, and fast. As a result, while it was previously possible to solve issues by treating only impacts because impacts were rather isolated from the whole system, this "painkiller" or "fireman" approach does not work anymore because all issues are now closely interconnected in space and time. For instance hunger and poverty of African nations is now closely linked to global warming, which, in turn, is mainly due to excess fossil fuel consumption of rich nations. Hunger and poverty in 
poor nations is also caused now by growing energy crops in rich nations. For instance switching the use of maize from food to biofuel has dramatically increased maize prices on the world market. Therefore, providing food to poor countries, the painkiller approach, will not succeed in the end if the energy issue is not dealt with at the same time. In that respect ecological activists were right in the 1970 s to claim that treating issue sources is better that treating impacts.

However, treating an individual issue source is not sufficient anymore today because all issue sources are closely linked. For instance, decreasing fossil fuel consumption in rich countries implies using cars less and less cars. This will be difficult on two grounds, at least. First, modern nations such as the United States of America have built their towns to fit with car use, with rather long distances from home to workplace and shopping malls. It will thus be difficult to turn back using bicycles. Europe is actually adapting better in that respect because towns were built in a much more concentrated way in the middle ages when citizens were walking. Nonetheless, all rich nation citizens should rethink their whole actual way of life, instead of applying the "I shop therefore I am" principle (Kruger, 1987). Second, the obesity issue in rich nations has increased so much that about half of people will not even be able to turn back to walking and cycling on health grounds (Wall-E, 2008). Unexpectedly, poor nations may adapt better in that respect, because they are less "artificialised". To conclude those examples demonstrate the dependence of seemingly independent, far-reaching issues: hunger in poor nations, global warming, energy crops, obesity in rich nations, spatial structure of modern towns, and so on. Other recent, striking examples that show that society issues have no frontiers are World Wars and Chernobyl. Advices to solve major society issues are given in my previous article (Lichtfouse, 2009a). I suggest in particular to study artificialisation, and to change sharply society structures to adapt to current issues.

\section{Sustainable agriculture for solving society issues}

All society issues such as health, hunger, poverty, climate change, energy, economy, employement, politics, and war are related to agriculture. Hunger and poverty in poor nations is related to crop production. Diseases in poor nations are linked to poverty, and, in turn, to competitiveness of agriculture in a global market. Fast-emerging health problems such as cancer are partly due to food and water contamination by pesticides and other agrochemicals. Atmospheric pollution is caused in part by trucks and planes carrying food over long distances. Industrial agriculture is transferring soil carbon in the atmosphere as $\mathrm{CO}_{2}$, and, in turn, increasing global warming. War is historically linked with agriculture because early agriculture was at the origin of territories and borders. War is economically related to agriculture, because wars are usually fought to control or develop markets. And so on. Agriculture is thus a central point to address most society issues. Here agronomists are thus the most advanced scientists because they are used to decipher complex scientific, social, political, and economic issues at various levels in space and time (Lal, 2009a,b, Lichtfouse et al, 2009a,b). Indeed, agronomists usually address a problem using the "system" approach that consider that a specific problem is never isolated and is part of a whole system of factors that can impact positively or negatively the problem. Now, by developing principles of sustainable agriculture, agronomists have thus the potential to solve not only common agricultural issues such as "low crop yield", but also world issues such as wars, poverty and climate change. 
This is the introductory article of volume 2 of the book series Sustainable Agriculture Reviews. I report my next essay in volume 3 (Lichtfouse, 2009b). Volume titles of Sustainable Agriculture Reviews are:

1. Organic farming, pest control and remediation of soil pollutants.

ISBN: 978-1-4020-9653-2. DOI: 10.1007/978-1-4020-9654-9

2. Climate change, intercropping, pest control and beneficial microorganisms.

ISBN: 978-90-481-2715-3. DOI: 10.1007/978-90-481-2716-0

3. Sociology, organic farming, climate change and soil science.

ISBN: 978-90-481-3332-1. In press.

4. Genetic engineering, biofertilisation, soil quality and organic farming.

ISBN: 978-90-481-8740-9. In press. 


\section{References}

Arrhenius S. (1896). On the influence of carbonic acid in the air upon the temperature of the ground. Philosophical Magazine and Journal of Science (fifth series) 41, 237-275.

Arrhenius S. (1908). Das Werden der Welten. Academic Publishing House. Leipzig.

EEA-JRC-WHO (2008) Impacts of Europe's changing climate. 2008 indicator-based assessment. ISBN 978-92-9167-272-8. DOI 10.2800/48117. http://reports.eea.europa.eu/eea_report_2008_4/en

Feehan J., Harley M., Minnen J. (2009) Climate change in Europe. 1. Impact on terrestrial ecosystems and biodiversity. A review. Agron. Sustain. Dev. 29, 409-421. DOI: 10.1051/agro:2008066.

Högbom A. (1894). Om sannolikheten för sekulära förändringar i atmosfärens kolsyrehalt. Svensk kemisk tidskrift. 4, 169-177.

IPCC (2007) Climate Change 2007: Synthesis Report. Contribution of Working Groups I, II and III to the Fourth Assessment Report of the Intergovernmental Panel on Climate Change. Core Writing Team: Pachauri, R.K and Reisinger, A.(eds.). IPCC, Geneva, Switzerland, 104 pp. http://www.ipcc.ch/ipccreports/ar4-syr.htm.

Jones A., Stolbovoy V., Rusco E., Gentile A.R., Gardi C., Marechal B., Montanarella L. (2009) Climate change in Europe. 2. Impact on soil. A review. Agron. Sustain. Dev. 29, 423-432. DOI: 10.1051/agro:2008067.

Keeling C.D. , Piper S.C., Bacastow R.B., Wahlen M., Whorf T.P., Heimann M., Meijer H.A. (2001) Exchanges of atmospheric $\mathrm{CO}_{2}$ and ${ }^{13} \mathrm{CO}_{2}$ with the terrestrial biosphere and oceans from 1978 to 2000 . I. Global aspects, SIO Reference Series, No. 01-06, Scripps Institution of Oceanography, San Diego, 88 pages.

Keeling C.D. , Piper S.C., Bacastow R.B., Wahlen M., Whorf T.P., Heimann M., Meijer H.A. (2005) Atmospheric $\mathrm{CO}_{2}$ and ${ }^{13} \mathrm{CO}_{2}$ exchange with the terrestrial biosphere and oceans from 1978 to 2000: observations and carbon cycle implications, pages 83-113, in "A History of Atmospheric CO2 and its effects on Plants, Animals, and Ecosystems". Editors: Ehleringer, J.R., T. E. Cerling, M. D. Dearing, Springer Verlag, New York.

Kruger B. (1987) I shop therefore I am. Artwork by Barbara Kruger. Shown in an article entitled "What politicians dare not say" by Tim Jackson (pp 42-43) that is part of a review article entiled "Why our economy is killing the planet, and what we can do about it", New Scientist, 18 October 2008, pp. $40-54$.

Lal R. (2009a) Soils and sustainable agriculture. A review. In Lichtfouse et al. (eds) Sustainable Agriculture, vol. 1, 15-23. DOI: 10.1007/978-90-481-2666-8_3.

Lal R. (2009b) Soils and food sufficiency. A review. In Lichtfouse et al. (eds) Sustainable Agriculture, vol. 1, 25-49. DOI: 10.1007/978-90-481-2666-8_4

Lavalle C., Micale F., Houston T.D., Camia A., Hiederer R., Lazar C., Conte C., Amatulli G., Genovese G. (2009) Climate change in Europe. 3. Impact on agriculture and forestry. A review. Agron. Sustain. Dev. 29, 433-446. DOI: 10.1051/agro/2008068.

Lichtfouse E. (2009a) Sustainable agriculture as a central science to solve global society issues. In: E. Lichtfouse (Ed.) Organic Farming, Pest Control and Remediation of Soil Pollutants. Sustainable Agriculture Reviews. Vol. 1. Springer, pp. 1-3. DOI: 10.1007/978-1-4020-9654-9_1 
Lichtfouse E. (2009b) Society issues, painkiller solutions, dependence and sustainable agriculture. In: E. Lichtfouse (Ed.) Sociology, Organic Farming, Climate Change and Soil Science. Sustainable Agriculture Reviews. Vol. 3. Springer, pp. 1-17. DOI: 10.1007/978-90-481-3333-8_1.

Lichtfouse E., Navarrete M., Debaeke P., Alberola C., Ménassieu J. (2009a) Agronomy for sustainable agriculture. A review. In Lichtfouse et al. (eds) Sustainable Agriculture, vol. 1, 1-7. DOI: 10.1007/978-90-481-2666-8_1

Lichtfouse E., Hamelin M., Navarrete M., Debaeke P., Henri A. (2009b) Emerging agroscience. Agron. Sustain. Dev. 29, 1-10, 2010. DOI: 10.1051/agro/200955

Scripps (2008) http://scrippsco2.ucsd.edu/program_history/keeling_curve_lessons.html

Wall-E (2008) Inspiring science fiction film directed by Andrew Stanton and produced by Pixar Animation Studios.

Weart S.R. (2008). The discovery of global warming. Harvard University Press. 240 p. http://www.aip.org/history/climate.

Wikipedia. http://en.wikipedia.org/wiki/Svante_Arrhenius.

http://en.wikipedia.org/wiki/Greenhouse_effect 